This item is the archived peer-reviewed author-version of:

Stemming the tide : what have European Union countries done to support low-wage workers in an era of downward wage pressures?

\title{
Reference:
}

Marchal Sarah, Marx Ive.- Stemming the tide : what have European Union countries done to support low-wage workers in an era of downward wage pressures?

Journal of European social policy - ISSN 1461-7269 - (2017)16 p.

Full text (Publisher's DOI): http://dx.doi.org/doi:10.1177/0958928717704747 


\section{Stemming the tide: What have European Union countries done to support low-wage workers in an era of downward wage pressures?}

Sarah Marchal

Ive Marx

Paper published online as Marchal, S., \& Marx, I. (2017) Stemming the tide: What have European Union countries done to support low-wage workers in an era of downward wage pressures? Journal of European Social Policy, $O(0)$, doi:10.1177/0958928717704747

\section{Introduction}

This article looks at government income policies vis-à-vis low-paid workers in Europe and the United States over the past 15 years. There are many reasons why this is a compelling subject for social policy scholars.

To start, the tide of late has not been favourable to less skilled workers in rich countries. With continuing deindustrialisation, automation and outsourcing, many less skilled workers have come to rely on service sector jobs which cannot be readily outsourced or automated, but where productivity and thus wage gains are also achieved less easily (Acemoglu and Autor, 2011; Atkinson, 2015). These trends are widely seen as potentially driving down low-skilled wages. In addition, there is increased competition for low-skilled jobs from (temporary) migrants in many countries (Eurofound, 2014). Whereas these changes impact on all rich countries, some of them may weigh more heavily within the common market of the European Union. 
Since the 2004 and 2007 enlargements, workers from the new member states (MSs) have gradually but altogether rapidly gained free access to the old EU countries, where wages and working conditions tend to be far better than in their home countries (Eurostat, 2015; Eurofound, 2014).

At the same time, and perhaps somewhat paradoxically, governments across Europe have been striving to get more people into the labour market, including those with the weakest work histories and skills profiles (Eichhorst and Konle-Seidl, 2008; Etherington and Ingold, 2012). Increasing the number of people in work was indeed at the core of the Lisbon Strategy and it remains central to the current Europe 2020 strategy (Van Rie and Marx, 2012; Kok, 2004; European Commission, 2010a). Persons facing multiple obstacles to ensure qualitative employment are explicitly included in this approach (European Commission, 2008). The notion that 'a job is the best protection against poverty' became a central tenet of EU policy during the Lisbon era and thereafter.

Trying to boost employment rates, especially among those at working age dependent on benefits, governments encountered at least two (perceived) barriers. First, significant numbers of the nonemployed faced limited financial incentives to take up low paid work, especially those primarily targeted for activation such as the unemployed and social assistance recipients (OECD, 1994; Immervoll, 2012). Second, it has become clear that moving into employment does not always mean an escape from poverty, especially for people with dependent children. Concurrent with longer standing concerns about child poverty, in-work poverty has gained prominence as a policy concern in Europe, especially as activation efforts intensified (Hanzl-Weiß and Vidovic, 2010).

The combination of these trends leads us to expect significant shifts in government policy vis-à-vis low paid workers. In this article we assess whether years of growing concern about downward pressure on wages, in-work poverty and 'making work pay' were actually reflected in policy changes. We focus on trends in minimum wages, tax relief measures, and benefits in a period of continued European integration 
and activation reforms. Our paper is distinctive in the sense that it aims to assess the combined impact of policy measures on the level of minimum income protection for workers, rather than focusing on single policy measures. Our research question is indeed to assess what governments have done, and which priorities and policy measures they favoured, rather than assessing the effectiveness or design of noncomparable policy instruments in a limited number of countries. Both from an incentives- and an antipoverty perspective, it has been demonstrated that coordination of policy measures is extremely important (Immervoll and Pearson, 2009; OECD, 2015a), as changes in particular anti-poverty or makingwork-pay measures have repercussions on eligibility or generosity of other types of government support. In this paper, we look precisely at this total effect on the potential effectiveness of minimum income protection, and assess how different components contributed to it. We entail an explicit poverty perspective, looking at the measures that are in place to guarantee a minimum income for workers (and hence not necessarily to incentivize benefit recipients to make the transition to work). We assess whether we find similar patterns within a selection of 15 EU countries, in the period 2001-2012. Three US states are included as reference cases, as the US is a country where low pay and in-work poverty is rife but also where much has been done to support low-paid workers. More specifically, we ask how minimum wages have responded to the increasing pressures on low-wage workers, and whether EU countries took measures to stem the tide for working low income families. Moreover, do we find evidence for similar policy instruments, and were similar groups singled out for support?

\section{Research questions}

What should we look for in the data and what would we expect to see? This section reviews the literature and formulates some expectations. We start off by discussing the literature pertaining to minimum wages. We then move on to tax and benefit policies, their relative role and potential differentiation by household situation. Inevitably, because of the broad scope of the paper in terms of income components, countries 
and time period covered, the level of detail of that discussion for each aspect under focus will be limited. There is a more extensive literature on each of these aspects, but the added value of this paper is that we see how various trends interact and 'add up'.

\section{What has happened to minimum wages?}

It is argued that global trends, including increasing international competition and automation, put pressure on low wages (Atkinson, 2015; Acemoglu and Autor, 2011). Kristal and Cohen (2016) demonstrate that the deterioration of labour market institutions, such as strong trade unions and adequate minimum wages, failed to protect American workers from these trends. Yet it is in no means self-evident that labour market institutions should dwindle in the face of adverse pressures. For instance, governments could want to strengthen minimum wages in reaction to an increased demand for more protective measures by their electorate (Vaughan-Whitehead, 2010).

It is therefore important to monitor what happened to minimum wages, as they make up an important part of the minimum income protection arrangements that are in place for workers (Marx, Marchal and Nolan, 2013). Moreover, they generally cater for the specific target group of low-skilled or young, starting workers, whose jobs may be especially likely to suffer from increasing global competition (Ryckx and Kampelmann, 2012).

More international competition became very real also in the single market for goods and services in the EU. Since its start, the EU pushed for a far driven economic integration. This ongoing process of economic integration of European labour markets has led many to expect increasing pressures on labour market institutions protecting workers, especially in countries where these are comparatively most extensive and generous (Kvist, 2004; Paetzold and Van Vliet, 2012; Scharpf, 2002; Van Vliet et al., 2010). Indeed, in 
guaranteeing a free market of goods, services, capital and persons, the EU boosts competition between Member States that differ substantially on social as well as economic accounts. The European Court of Justice has often ruled in favour of this free market as opposed to safeguarding more protectionist acquired rights (e.g. the Viking and Laval arrests, see Verschueren, 2015). But also fears (imaginary or not) that migrants from poorer MSs will move to richer MSs not solely for improving their labour market prospects, but also attracted by their social provisions are relevant in this regard (Kvist, 2004; Cameron, 2013).

It is then feared that governments might enter into an underbidding strategy (a 'race to the bottom'), making their country relatively more attractive to investors and less attractive to migrating EU citizens. A counterargument to this expectation of downward pressures and convergence posits that precisely because of this increased insecurity, the local political demand for social protection will rise (VaughanWhitehead, 2010). Combined with the rising prosperity in the poorer EU Member States, a number of authors argue against this race to the bottom argument, and some even expect an upward convergence or convergence to the middle through catch-up growth (e.g. Paetzold and Van Vliet, 2012).

Up till now, such trends have mainly been researched for social benefits (Draxler and Van Vliet, 2010; Montanari et al., 2008; Schmitt and Starke, 2011) and employment protection legislation (Erhel and Zajdela, 2004; McBride and Williams, 2001; Skedinger, 2010), rather than for the specific case of minimum wages. Moreover, evidence from this literature remains rather inconclusive. This paper therefore contributes in assessing which minimum wage trends are more likely: a general erosion relative to living standards or even (in a genuine race to the bottom) in real terms, positive trends in formerly unprotective countries, or an overall increase in response to the increased insecurity for low wage workers?

\section{Making work pay?}


The adverse pressures on low wage workers did not sway society's and policy maker's stances on activation. Getting more people into paid employment became the tenet of EU-wide social policies. During the 1990s social policy at EU level and in many countries became increasingly strongly focused on increasing the number of people relying on earnings. Getting more people in work was a core objective of the Lisbon Agenda (2001-2010). At the same time, international organisations like the OECD were continuing if not intensifying long-standing calls for getting more people in work and off benefits, especially as economic conditions were favourable (OECD, 1997; OECD, 2003). National policy discourse in many countries also echoed the importance of employment growth (Aust and Arriba, 2005; Eichhorst et al., 2008). Of course, the notion that the unemployed should look for work was not new. The main innovation of the general adoption of the activation paradigm since the nineties, was the extent to which this expectation was broadened to include ever larger target groups, including less productive workers (Bengtsson, 2014; Etherington and Ingold, 2012). Eichhorst \& Konle-Seidl (2008) describe how activation measures were newly applied to social assistance recipients, a group formerly seen as too marginal and on a too large distance from the labour market. More noteworthy, also spouses in breadwinner couples or lone parents were specifically included (Skevik, 2006; Annesley, 2007). The example of the UK is telling in this regard, that transferred an ever larger group of jobless lone parents from income support to the jobseeker's allowance in the course of the 2000s. In fact, Annesley (2007) considers this to be the main innovation of the Lisbon agenda. MSs are moving away from the male breadwinner model as the traditional underpinning of their welfare state policies (a basis that is especially apparent in the continental and Southern European states) (Bradshaw and Hatland, 2006), and moving forward to an adult worker model, where social policies will be oriented around the assumption that anyone who can will work (Annesley, 2007; Daly, 2011; Knijn et al., 2007). This should not necessarily mean a withdrawal of the welfare state, but rather a reorganization of policies. 
Indeed, one would expect this embracing of the activation paradigm to have prompted significant changes in tax and benefit policies, and this for the following reasons.

First, because of widespread and longstanding concerns about weak work incentives standing in the way of effective activation efforts. Politicians in many countries echoed popular concerns that "work does not always pay", especially for persons on benefits with limited earnings potential. Perhaps realizing that there were limits to handling this problem by cutting down on benefits or imposing tighter restrictions on prolonged benefit receipt on the one hand or by increasing minimum wages on the other (see preceding section), governments may have focused on making work more attractive by increasing take home pay through changes in tax and benefit systems. It is certainly the case that supranational entities like the OECD and the European Commission were stating that increased take-home pay was an indispensable element of an effective activation strategy (European Commission, 2008; OECD, 2009; Immervoll, 2012; Weishaupt, 2011).

Second, in-work poverty started to come to the fore as public policy concern during the 2000s. Long considered an American phenomenon, the realization that in-work poverty was also a real issue throughout Europe came as figures and studies started to emerge on this topic from the late 1990s (Marx and Verbist, 1998; Halleröd et al., 2015; Crettaz, 2013). Also, the Laeken indicators adopted by the EU in 2001 to monitor progress in the social field in the EU contained breakdowns of poverty by employment status, bringing this issue firmly and structurally into focus (Atkinson et al., 2002). At the same time it was becoming clear that child poverty, another topic that had come to the fore, was not restricted to households with no or weak work attachment (Van Mechelen and Bradshaw, 2013). A significant proportion, if not the majority, of children growing up in financial poverty were found to live in households mainly reliant on earnings. 
Finally, the shift towards activation and an adult worker model brings a new target group of in-work support into focus, i.e. families who, despite their full-time (or substantial) involvement in the labour market, do not succeed to escape poverty. An obvious case is a working lone parent. Indeed, child poverty rates show that poor children with at least one working parent disproportionally live in lone parent households (Vandenbroucke and Vinck, 2013). A single low wage no longer suffices to protect a family against poverty. In the case of a working lone parent, it is obvious that further increasing the labour market attachment of the household cannot provide solace.

In sum, there are good reasons to believe that policy makers had strong incentives to target additional support to low income working families, and indeed they had the policy instruments to do so. European welfare states are equipped with relatively well-functioning tax- and benefit systems, designed to offer additional income support to diverse target groups. We want to assess in this paper how and to what extent such policies were used to offer minimum income support to those in-work.

An interesting question here is what type of policy instruments were favoured by the European governments.

Over the past decade or so, international organizations and scholars alike have started to highlight the potential of tax systems to target support to low income families (Immervoll, 2007; OECD, 2005). Using the tax systems to support particular families is of course not new. Their progressive design and the often large tax allowances for dependent family members are only some examples of how tax systems seek to reinforce social policy (Adema, 1997).

However, some fiscal instruments are more recent. A particular type of tax benefit is a tax credit, a tax benefit that is subtracted from the final tax liability. To the extent that these tax credits are refundable, they may even result in a net benefit to families with low tax liabilities. The Anglo-Saxon countries were quite early in taking this aspect of taxation one step further, installing (initially relatively minor) tax credits 
already in the 1970s and 1980s. The two most well-known examples, the Earned Income Tax Credit (US) and the Working Tax Credit (UK), target low income working families, with more generous rates for families with children. Eventually, additional tax credits got introduced, for children and child care costs.

Looking further at child support, Ferrarini et al. (2013) argue that there has been a tendency towards a fiscalization of child support in a significant number of Western countries. They argue that child support tends to be more and more organized through a combination of tax credits, tax allowances and benefits, rather than through benefits solely. Given the ample policy attention the Anglo-Saxon working tax credits have garnered, this trend may well extend beyond child support, to support towards low income (working) families more generally.

\section{Data \& Method}

This contribution assesses trends in minimum wages and related income components in a cross-nationally comparable way by using standard simulations. Standard simulations are calculations of the net disposable income and its components for a model family, according to the applicable tax benefit rules. The characteristics of the model family are defined by the researcher and depend on the research question. The simulations used in this contribution are taken from the expert-sourced CSB-MIPI dataset. Country experts perform the standard simulations based on a uniform set of assumptions that aim to maximize cross-national and cross-temporal comparability, as well as to gauge minimum income situations. The CSB MIPI data set is comparable to other model family simulation data sets, such as SAMIP (for social assistance benefits only) and the OECD Benefits and Wages data. Its main advantage - at least for the purpose of this paper - is that it explicitly instructs country experts to give background information on the minimum wage 
cases used in this paper, through a standardized questionnaire. Results were validated against the OECD Benefits and Wages data.

In this contribution, we use the simulations of net disposable income for a 35 -year old single and couple, either childless or with two children aged 7 and 14 . The model families are assumed to have no savings or income other than the earned wage and income supplements provided by the tax benefit scheme. In each family, one adult works full-time, and is remunerated at the minimum wage. If present, the second adult in the household is assumed to be inactive. The wage is the national minimum wage, in full-time employment. ${ }^{1}$ Moreover, families are assumed to be tenants, and to pay a rent equal to two third of median rent. The simulations reflect the situation in June 2001 and January 2012. As the model family type is defined in the same way in all countries, results are comparable and only indicate genuine policy changes rather than labour market or demographic changes. A drawback of standard simulations is that the results are solely based on highly stylized family types that are not necessarily as common in each country under observation (see Van Mechelen et al., 2011: for a more thorough discussion of this issue).

Yet they allow for a thorough and detailed analysis of trends in supportive income policies. We track trends towards fiscalization and lone parent support by exploiting the fact that model families are alike in all characteristics but the presence of children in the household. Specifically, we calculate the child income tax benefit, total child effort and total net support. The child income tax benefit is defined as the difference in income taxes paid by a model household with children to those paid by the same model household without children. Total child effort is calculated by subtracting the net income of a family without children from the income of a similar family type with children. Both indicators act as measures of respectively the tax advantage and the total net income support awarded solely because of the presence of children in the

\footnotetext{
${ }^{1}$ A widely accepted definition of full-time employment does not exist. The number of hours required in a full-time job differs between sectors and between countries. The simulations assume full-time employment for each country, in line with national regulations. Where these are lacking, we follow the national expert's judgment.
} 
household (for a similar approach, see Van Lancker and Van Mechelen, forthcoming). We track trends in the relative share of the child income tax benefit in total child effort to gauge changes in the importance of fiscal benefits. Total net support is defined as the difference between the net income and the minimum wage of a model family (or, put differently, the sum of all benefits minus taxes and social insurance contributions). We track trends in relative net support towards lone parents versus couples to assess whether support has been directed more towards lone parent families as compared to breadwinner couples with children. A similar approach was used by Van Lancker et al. (forthcoming).

Trends in minimum wages and related net incomes are assessed in real terms, against average wages and median equivalent household income. These indicators are taken from Eurostat (2015) and the OECD (2015b). ${ }^{2}$ In addition, the robustness of minimum wage trends is assessed through the use of time series data of monthly minimum wages on top of trends in simulated minimum wages for a full-time working 35year old in June 2001, to assess the impact of different reference dates, working hours and experience related top-ups in some countries.

CSB MIPI comprises information for all EU MSs bar Cyprus, Malta and Croatia. We assess trends in minimum income protection for workers in all countries where a statutory minimum wage applied over the entire period. Unfortunately, discontinuity in the underlying work hour assumptions preclude the inclusion of Greece, Ireland, the Netherlands and Bulgaria.

\footnotetext{
${ }^{2}$ We take these indicators as they are provided by these organisations. Some caveats apply: median equivalent household income provided by Eurostat is based on the ECHP for 2001 and for 2009 and 2012 on the EU-SILC. Real terms are calculated using the harmonized indices of consumer prices from Eurostat. We use the HICP based on final household consumption expenditure. It should however be noted that the basket of goods and services is not necessarily fully representative for low income families. Nonetheless, we consider the use of these indicators justified, as they offer the best comparable time series of consumer price indices and living standards currently available for the EU Member States.
} 


\section{Results}

\section{Minimum wages under pressure?}

A first issue we seek to address in this contribution is how minimum wages changed over the past decade.

A first observation here is that national statutory minimum wages have become more prevalent across the EU, not less. Nearly all EU MSs have a statutory minimum wage today. There remain some exceptions, most importantly the Scandinavian countries, Austria, Italy and until very recently Germany ${ }^{3}$. Despite its prevalence, large variation exists in minimum wage levels. Within the EU, the highest minimum wage outranked the lowest by a factor of 5 in purchasing power standards in 2012. Self-evidently, the variation is smaller in relative terms, but even relative to gross average wages, the highest minimum wage is still nearly twice as high as the lowest.

In Figure 1 we show minimum wage trends from June 2001 to January 2012 for the countries included in our analysis. Countries are ranked according to the 2001 minimum wage level, in real (panel A) or relative (panel B and C) terms. Figure 1 does indeed show stagnating minimum wages in countries where these were initially rather high, albeit far more explicitly in real than in relative terms.

\footnotetext{
${ }^{3}$ That is not to say no wage floors exist in these countries. Generally, workers are covered by sectoral agreements in these countries Vaughan-Whitehead D. (2010) The minimum wage revisited in the enlarged EU, Cheltenham: Edward Elgar.. Austria has moved farthest towards a nation-wide wage floor, with its 2009 agreement between the national employer and employees representatives European Commission. (2010b) Industrial relations in Europe 2010, Luxembourg: Publications Office of the European Union..
} 
Relative to average wages, minimum wages did not keep pace in Belgium, the Czech Republic and France ${ }^{4}$. Figure 1 furthermore shows decreases for Lithuania and Romania ${ }^{5}$. Trends are even stronger relative to national poverty thresholds (i.e. $60 \%$ of median equivalent household income). Taking the median equivalent income as proxy for the average living standard in a country, we find that relative minimum wages have eroded in around half of the countries: in relatively generous Belgium and France, but also in Poland, Lithuania, Estonia and the Czech Republic. On the other hand, relative minimum wages increased substantially in Hungary, Slovenia and the UK.

In sum, there are large country differences in the development of minimum wage values in the $2000 \mathrm{~s}$. In real terms, these country differences are divided across the line of old versus new EU MSs, with relatively stagnant real minimum wages in the old EU MSs and substantial increases in the new MSs. The average increase in the new MSs is over $60 \%$, whereas it is only $8 \%$ in the old MSs included in our sample. Yet this outspoken difference disappears when we compare the trends of relative minimum wages between both country groups. Whereas the average trend in the new member states is always more positive than it is in the old MSs, the differences become quite small indeed (see panel B and panel C).

The real trends translate in a substantial convergence of minimum wages (coefficient of variation decreased from 0.76 to 0.56 ). Relative to average wages, the decrease in variation is far less pronounced, but self-evidently, variation was far more limited to begin with. The coefficient of variation decreased from

\footnotetext{
${ }^{4}$ This reflects the reduction in legal working time in full-time employment from 39 hours per week in 2001 to 35 hours per week in 2012.

${ }^{5}$ At the start of the period under observation, both countries still experienced large hikes in minimum wages, average wages and inflation rates. The results for these countries are therefore influenced to some extent by presenting the June 2001 minimum wage relative to the annual average wage.
} 
0.2 to 0.14 for the countries in our analysis, and the average level of the relative minimum was very nearly equal in both country groups by 2012. Variation in trends relative to the median equivalent household income remained stable, moreover the new MSs average remains substantially below the Old EU MSs average $^{6}$. All in all, these results do not point towards a universal race to the bottom within the EU. Rather, we find indications for a modest convergence to the middle, where there are both winners and losers.

\footnotetext{
${ }^{6}$ We checked these results (based on the countries for which we have standard simulations referring to June 2001 and January 2012) also on time series data, including a broader group of countries and with different reference dates.
} 
Figure 1: Percentage changes in gross minimum wages, 2001-2012

A. In real terms

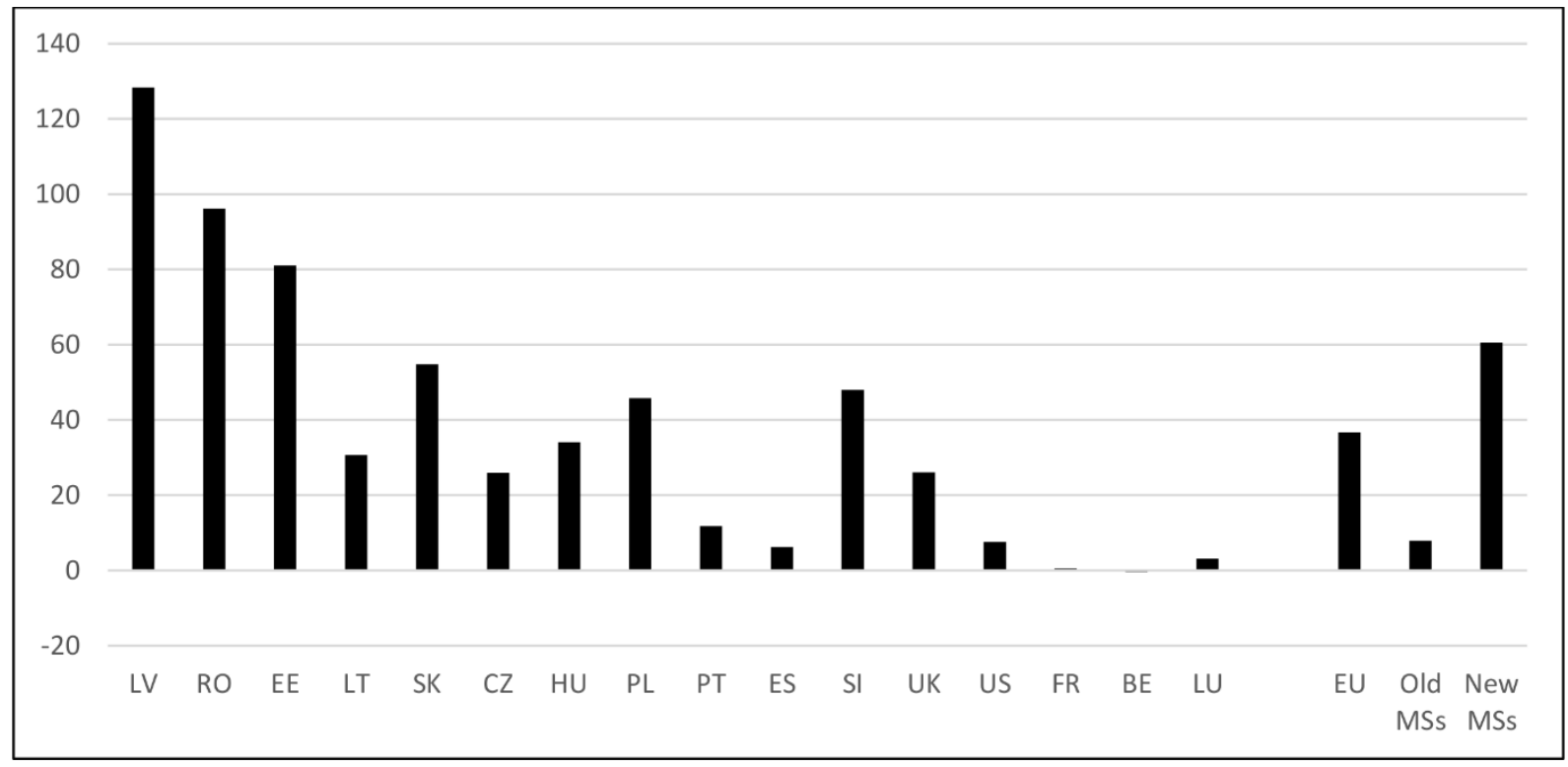

B. Relative to average gross wage

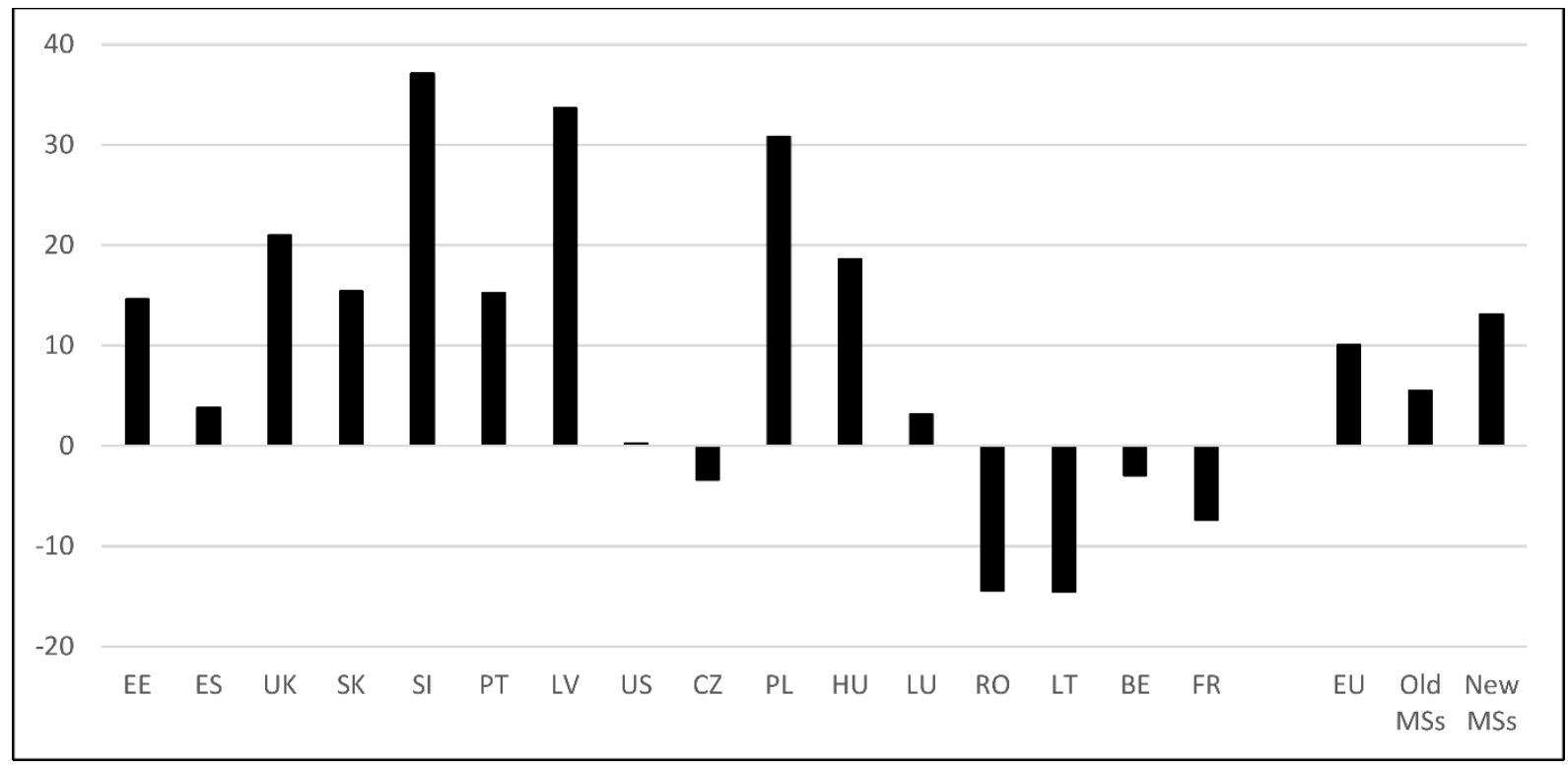


C. Relative to median equivalent household income

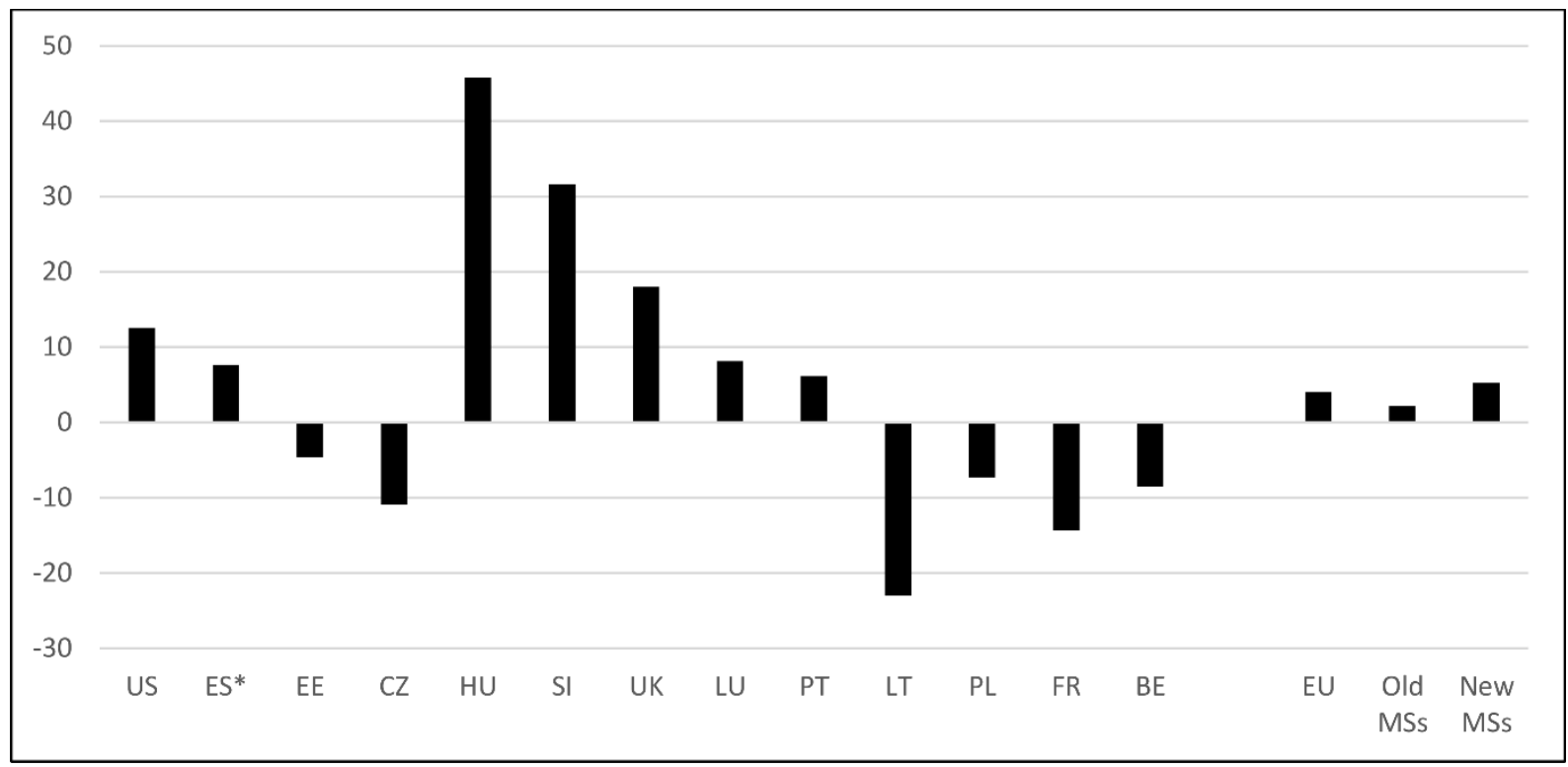

Notes: Simulated minimum wages for a 35-year old full-time employee, June 2001 and January 2012. Countries are ranked according to the 2001 level. Trends 2001-2012 are equal for the three US states included (Nebraska, New Jersey, Texas). ES: trends 2001-2009. No information on median equivalent household income available for LV, RO and SK for 2001.

Source: CSB-MIPI Version 3/2013 (Author, 2011); Purchasing power parities, harmonized indices of consumer prices and median equivalent household income from Eurostat (2015); average wages from OECD (2015)

Overall trends in the adequacy of net income of minimum wage workers

Figure 2 compares trends in minimum wages and simulated net disposable income at a full time minimum wage relative to the poverty threshold, for different household types. Other than in figure 1 , for the ease of presentation changes are presented as percentage point differences relative to the individual typical family's at-risk-of-poverty threshold (60\% of the median equivalent household income). Therefore, 
changes that are nominally the same for the different household types (such as the change in the minimum wage) will differ when expressed relative to the family's poverty threshold. We focus in this discussion on the relative difference between income components within the same household type.

Generally, trends in net incomes were more favourable than trends in minimum wages (i.e. the white diamonds indicating trends in net disposable income in figure 2 are generally above the black bars depicting the percentage point change in the national minimum wage). This is the case both for countries where minimum wages were left to erode as where they were increased. Yet, there are large differences between different family types. The net disposable income of a single person household developed far more favourable than the minimum wage in Lithuania, Belgium, the Czech Republic and Slovenia. In contrast, net disposable income lagged behind trends in the minimum wage in Estonia and Hungary. In the other countries included in figure 2 panel A, trends of gross and net incomes were relatively similar, at least for this family type. On average over the EU countries, the difference in changes of the minimum wage vis-à-vis the net disposable income remains relatively limited for a single person household. Both at the start and at the end of the decade, this family type did not receive much additional support (benefits, the white bars in figure 2, representing the combined impact of social assistance benefits, housing allowances and other non-discretionary and non-contributory cash support). Taxes (the grey bars, representing the combined impact of social insurance contributions, income and local taxes) did decrease substantially in a number of countries (and hence had a positive impact on the net disposable income). This was mainly in the rare countries where taxes were still relatively high at the start of the decade, such as in Lithuania or Belgium. Tax liabilities were decreased in various ways, including tax allowances or credits, and social insurance rebates. Figure 2 panel A clearly shows the exceptional position of Hungary: net disposable income clearly lagged behind trends in minimum wages, due to a substantial increase in the minimum wage, combined with an increase in tax liabilities. In fact, the minimum wage increase was 
(at least partially) implemented in order to counteract the effects of the flat tax reform that abolished most tax allowances.

The differences between minimum wages and net disposable incomes become more outspoken when there are more members in the household, as these family types generally rely more on additional government interventions. Most importantly, the benefits category includes for family types with children often a sizeable portion of child benefits. Means-tested housing allowances and social assistance benefits take account of the greater need experienced by larger families. Similarly, tax liabilities are generally lower for families where there are more dependents present. It then comes as no surprise that minimum wage and net income trends generally diverge more for larger families, than for a single person household. Panels B, C and D of figure 2 show the percentage point changes relative to the at-risk-of-poverty threshold of taxes, benefits, net incomes and minimum wages for a breadwinner couple with and without two children, and a lone parent with two children. For all three family types, net incomes only fare substantially worse than minimum wages in the Czech Republic, Estonia and Hungary. For breadwinner couples, nets lag slightly behind in Portugal and Spain, and for families with children in the UK, although in all three cases the actual differences are negligible. On average however, net disposable income is generally boosted over and above minimum wage trends, and this is especially the case for lone parent households. In addition, for this family type, the more positive development of net disposable income is apparent for both old as new EU Member States, as well as the US reference cases. For breadwinner couples, the trends in Estonia, Hungary and the Czech Republic outweigh the more limited positive trends in the other three new Member States included.

What policy measures were used to boost net disposable incomes over and above trends for gross minimum wages? Figure 2 shows the impact of changes in the broad tax (grey bars) and benefits (white bars) categories to the changes in net disposable income. Whereas for single person households, changes 
are especially due to taxes (also as this family type generally does not receive substantial benefits), for the other three family types presented in figure 2 , the impact of both income component categories is more balanced over the different countries included.

However, these trends in broad income categories hide significant international variation.

Positive changes to the income tax system were quite common. Benefiting from child tax allowances and tax credits, tax liabilities for low wage families with children were already very low to begin with, but even so, further decreases were common. By 2012, average tax rates for low-wage families with children in most countries approached zero.

In Table 1, we illustrate this point further focusing on the lone parent case, showing the decrease in overall income tax rates for this family type in 2001 and 2012. Overall, the average tax rate decreased by 4.57 percentage points in the EU. Most MSs introduced decreases, yet scope for further reduction was more limited in the old MSs, that had relatively lower taxes to start with. Also, the UK reduced the generosity of its child tax credit over this period. In contrast, the average decrease in tax rates for a lone parent family among the new MSs amounted to 8.75 percentage points. As for singles, the decreases were quite pronounced in Lithuania, which in 2001 still had a relatively substantial tax liability for this family type. Also in the Czech Republic and Slovakia, the tax liabilities decreased substantially, as both countries introduced a substantial child tax credit (that replaced however part of the child benefit). Finally, tax rates decreased even further for this family type in the US, mainly due to the temporary expansion of its tax credits.

This rather general reduction of income tax rates for lone parents with children begs the question whether this is part of a more general restructuring of welfare state support to low income households to be delivered through the tax system, rather than through traditional benefit schemes. Ferrarini et al. (2013) note such a trend for the child benefit system, terming it the fiscalization of child support. The first two 
columns of Table 1 aim to shed some light on this issue, for the specific case of a lone parent family. Here we show the share of child support that is provided through the tax system (see data section for details on the calculation). On average for the EU, around one fifth of child support received by a working lone parent with two children is provided through reduction in income tax liabilities or child tax credits. This stands in stark contrast to the practices in Anglo-Saxon countries, where over half of child support is provided in such as way. This ratio has increased over the period 2001-2012 in around half of the EU MSs. Yet there are important exceptions, such as Lithuania and Slovenia, where more classic benefits were introduced or raised.

Trends in the other income components are even more dispersed. Social insurance contributions are generally the same for all family types, in line with their individual, contributory logic. Yet some countries, including Belgium, sought to circumvent this logic by introducing substantial social insurance rebates for low wage workers. A number of Eastern European countries on the other hand added insurance categories. Child benefits generally remained fairly stable or decreased. The most important exception was Lithuania, that implemented a child benefit scheme. Poland and Belgium raised the child benefits for lone parent families. Trends in social assistance top-ups are difficult to interpret. Social assistance is a means-tested, residual benefit. It often takes all possible income sources into account (in some countries child benefits or housing allowances may be disregarded). The changing impact of social assistance topups on net disposable income therefore not necessarily reflects policy changes with regard to social assistance, but may well reflect changes to the other income components discussed above. Yet there are solid indications that some countries sought to promote social assistance top-ups to low income working families. This was precisely the point of the 2009 French social assistance reform. Similarly, clear policy choices seem to be behind changes in social assistance top-ups in Portugal and the Czech Republic. Finally, the Slovenian increase is due to the extension of eligibility to its housing allowance scheme in late 2001, leading to a substantial increase in the importance of this income component. 
Figure 2. Trends in net income package and its components of a one-earner family, employed at minimum wage, 2001-2012 (ppt change, relative to $60 \%$ of median equivalent household income)

Panel A. Single person household

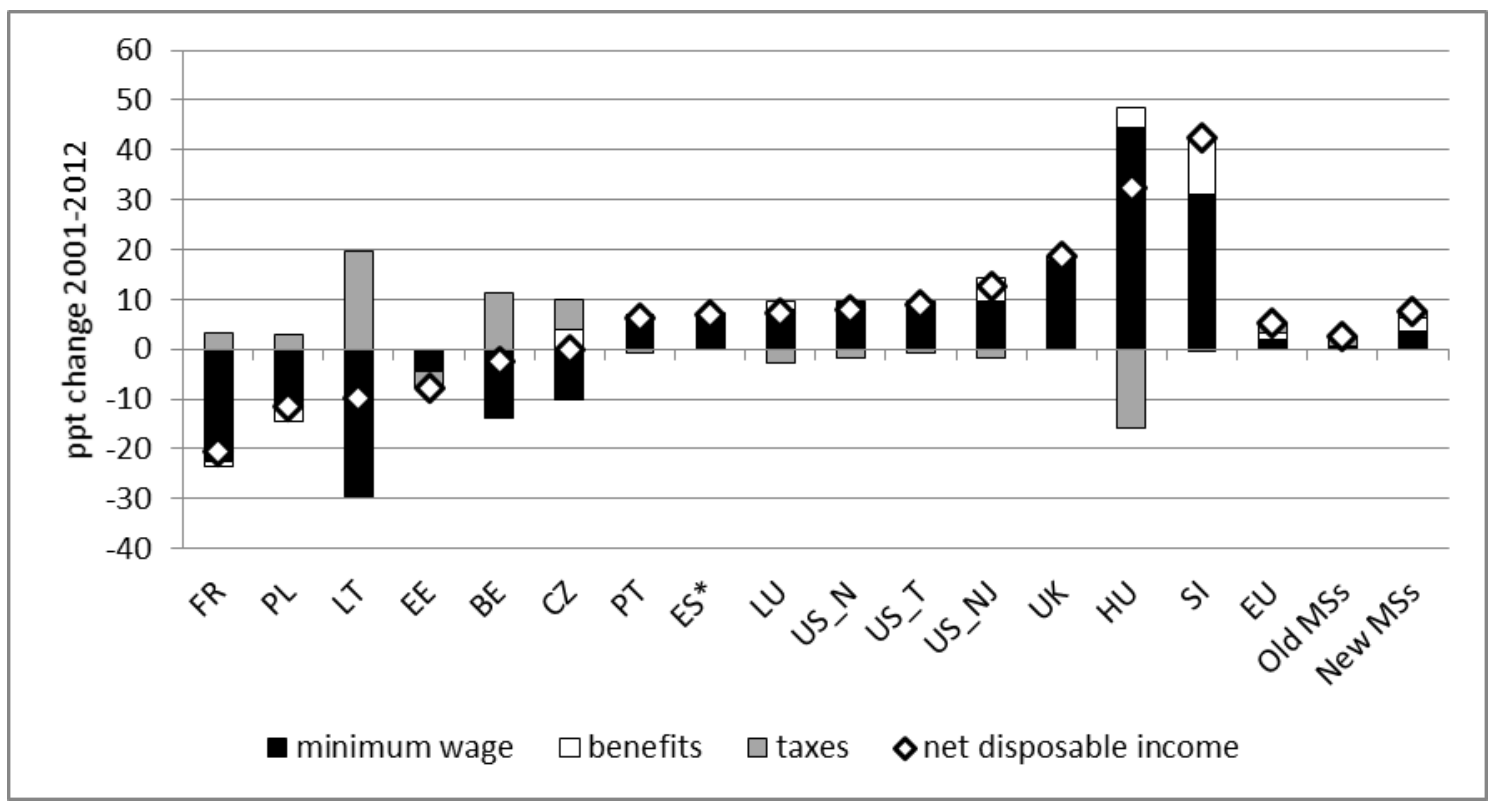

Panel B. Couple household

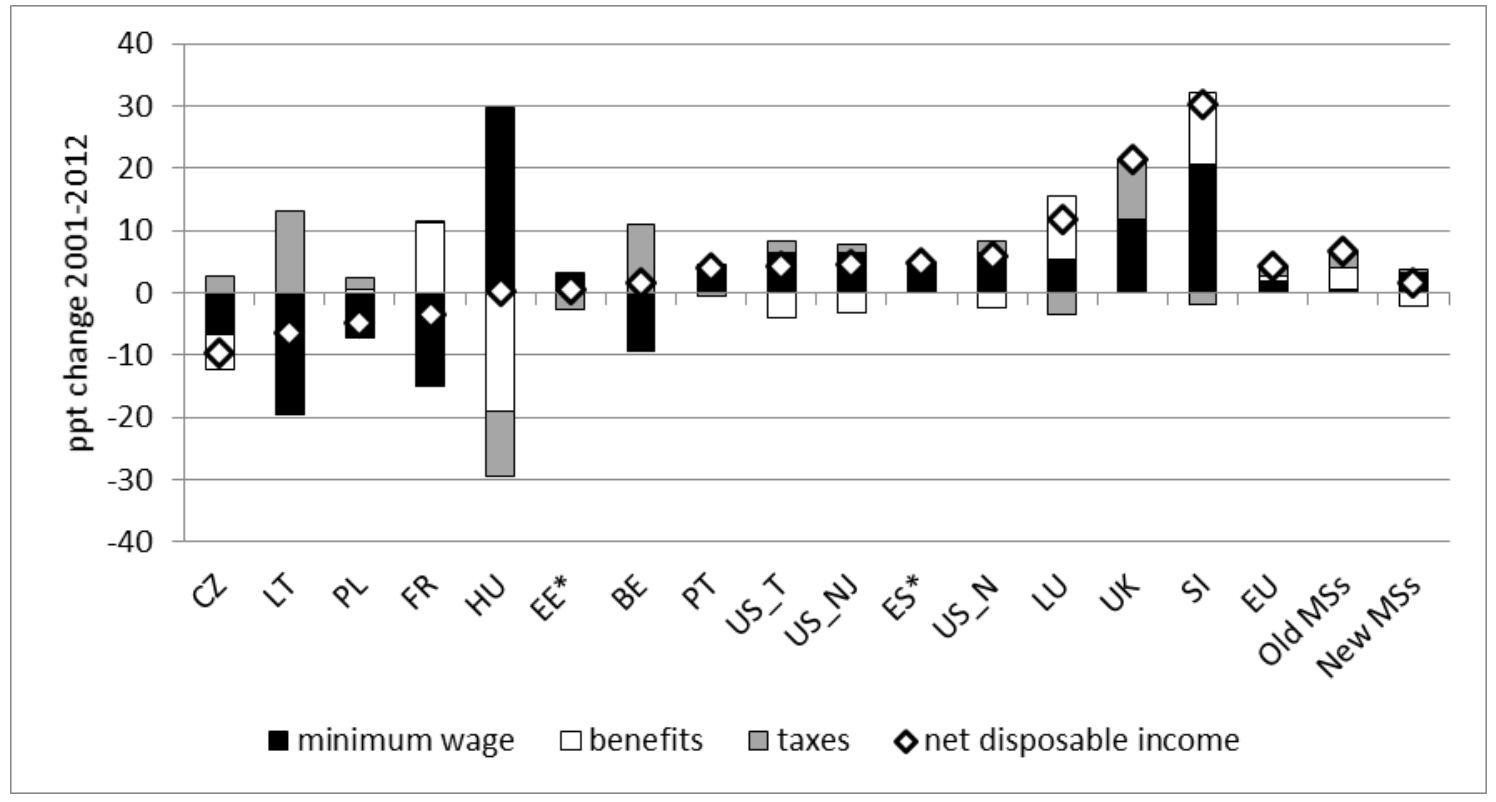


Panel C. Couple with two children

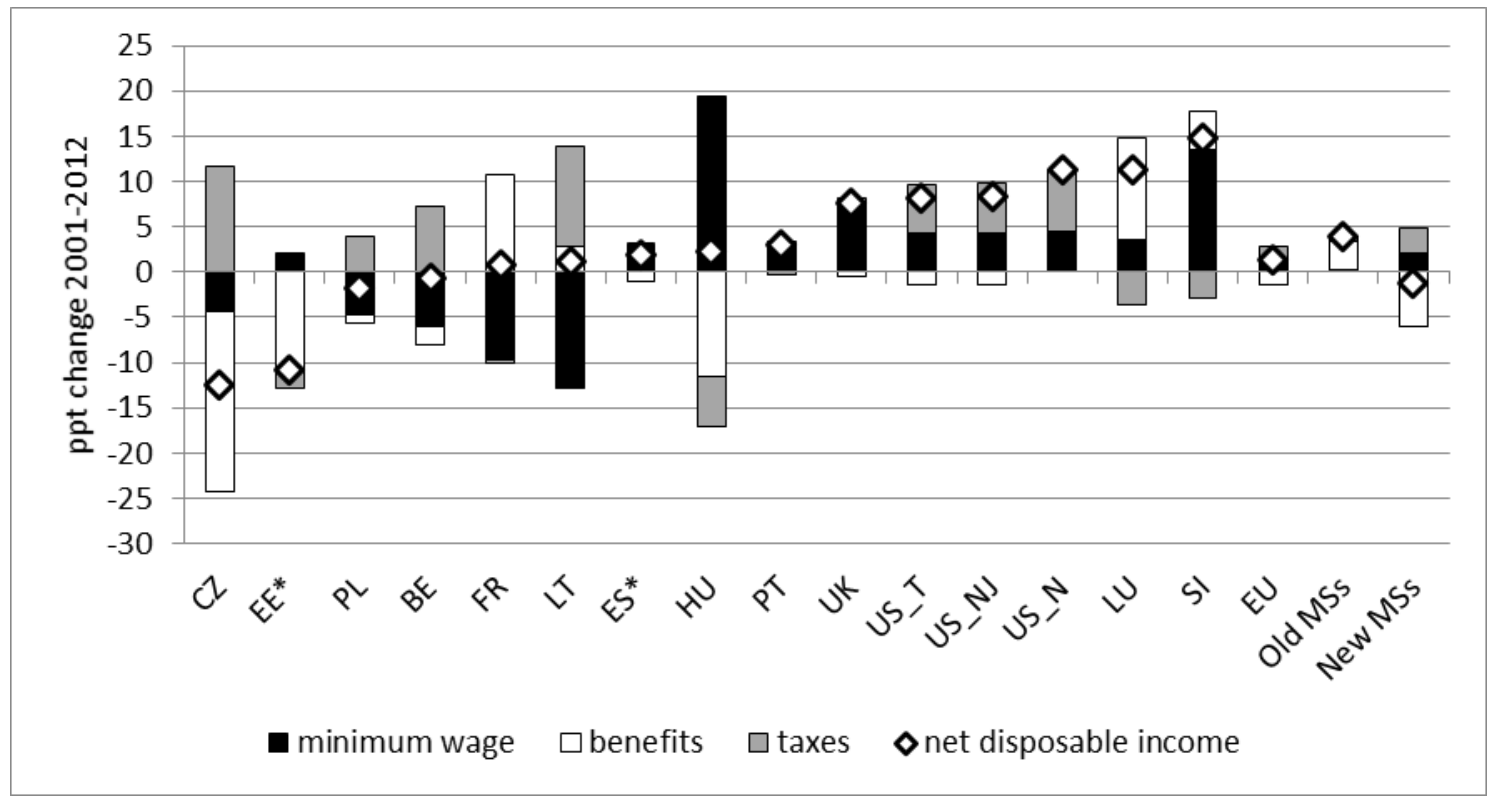

Panel D. Lone parent with 2 children

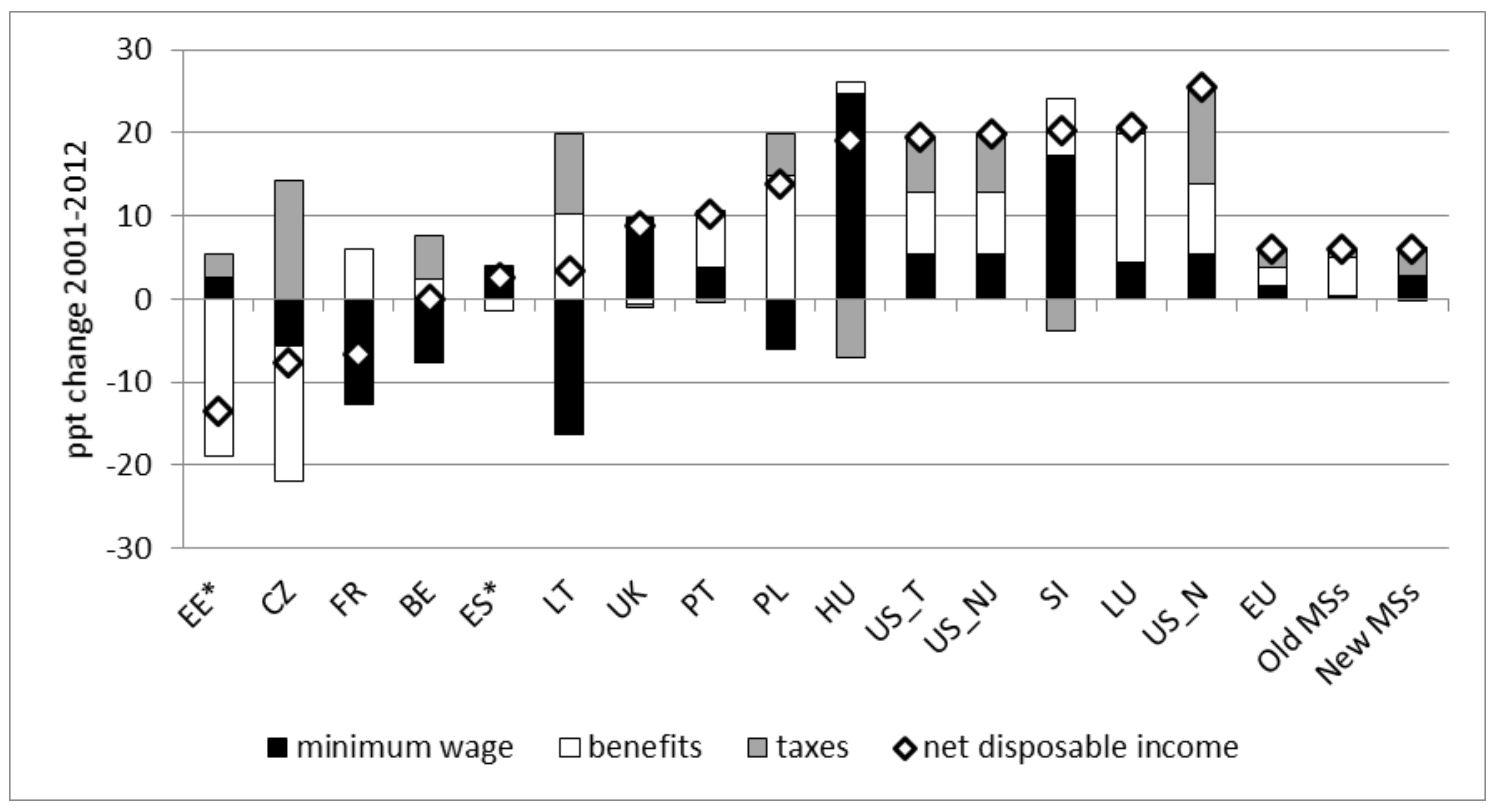

Notes: US_N: Nebraska; US_NJ: New Jersey; US_T: Texas. *EE and ES: 2001-2009

Source: CSB MIPI Version 3/2013 (Author, 2011), 60 \% of median equivalent household income from Eurostat (2015) 
Self-evidently, these changes had different repercussions over the various family types. Figure 2 already hinted that the increase in additional support was more substantial and general for lone parent families. In the two most right columns of table 1 , we further look into this matter. These columns show the ratio of total net support received by a lone parent family, as compared to the total net support received by a couple with two children (see data section for the precise calculations). Bar a few exceptions, this family type generally received less net support than a couple with two children in 2001. This is unsurprising, as most means-tested benefits, that are included in our calculation of net support, take account of the additional need represented by the extra adult in a breadwinner couple household. However, by 2012 , the ratio had generally increased, and even to such an extent that the ratio of net support received by a lone parent family on average surpassed the support received by a couple with 2 children, that for all intents and purposes but the additional adult was exactly the same. With the sole exception of France, this trend holds for old as well as new EU MSs, and for the US.

The drivers of these increases are diverse, and include measures such as categorical child benefit supplements to lone parent families and tax benefit for lone parents. Their common denominator is the explicit recognition that lone parent families are entitled to additional support. For another measure, this is less clear. The lone parent type case also advances relative to a breadwinner couple with 2 children due to shifting eligibility to and levels of social assistance. Indeed, the activity requirements in some social assistance schemes make breadwinner couples ineligible, a reservation that does not apply to a working lone parent. 
Portugal is a prime example in this regard. Note that in France, breadwinner couples remained eligible for a social assistance top-up. In fact, the exceptional finding that relatively more support was directed towards breadwinner couples than to lone parent families in this country, is driven by the higher social assistance top-up a couple with children receives. The general pattern however is clearly different and points towards more supportive measures towards a family type that is especially vulnerable, despite already having reached its full earnings potential. 
Table 1: Fiscalization and support towards lone parent households, 2001-2012

\begin{tabular}{|c|c|c|c|c|c|}
\hline & \multicolumn{2}{|c|}{$\begin{array}{c}\text { Share of child income tax } \\
\text { benefit as \% of total child } \\
\text { effort }\end{array}$} & \multirow{2}{*}{$\begin{array}{c}\Delta \text { income tax } \\
\text { rates } \\
2001-2012\end{array}$} & \multicolumn{2}{|c|}{$\begin{array}{l}\text { Ratio net support to lone } \\
\text { parent versus couple families }\end{array}$} \\
\hline & 2001 & 2012 & & 2001 & 2012 \\
\hline $\mathrm{BE}$ & 0.29 & 0.24 & -1 & 0.24 & 0.66 \\
\hline$C Z$ & 0.04 & 0.33 & -28 & 0.72 & 0.83 \\
\hline $\mathrm{EE}^{*}$ & 0 & 0.25 & -10 & 1.33 & n.a. \\
\hline ES* & 0 & 0 & 0 & 1 & 1 \\
\hline FR & 0.09 & 0.02 & 2 & 0.98 & 0.73 \\
\hline HU & 0.28 & 0.32 & -3 & 0.56 & 1.06 \\
\hline LT & 0.33 & 0.13 & -17 & n.a. & 0.45 \\
\hline LU & 0.07 & 0.12 & -5 & 0.26 & 0.54 \\
\hline PL & 0 & 0.1 & -1 & n.a. & 3.09 \\
\hline PT & 0 & 0 & 0 & 1 & 3.81 \\
\hline RO & 0.02 & 0.16 & 3 & 1 & n.a. \\
\hline SI & 0.16 & 0.04 & 0 & 0.44 & 0.52 \\
\hline SK & 0.03 & 0.28 & -14 & 0.48 & 0.56 \\
\hline UK & 0.83 & 0.81 & 10 & 1.02 & 1.01 \\
\hline US_N & 0.61 & 0.61 & -19 & 0.84 & 1.18 \\
\hline US_NJ & 0.61 & 0.62 & -9 & 0.86 & 1.12 \\
\hline US_T & 0.57 & 0.55 & -9 & 0.85 & 1.13 \\
\hline EU & 0.15 & 0.2000 & -4.57 & 0.75 & 1.19 \\
\hline Old MSs & 0.21 & 0.1983 & 1.00 & 0.75 & 1.29 \\
\hline New MSs & 0.11 & 0.20 & -8.75 & 0.76 & 1.09 \\
\hline
\end{tabular}

Notes: * EE, ES: 2012 n.a.; 2012 data refer to 2009. UK: housing allowances are not included due to comparability issues. US_N: Nebraska; US_NJ: New Jersey; US_T: Texas

Source: CSB MIPI Version 3/2013 (Author, 2011) 


\section{Conclusion}

This contribution has looked at trends in the net take home pay of full time persons working for the minimum wage, accounting for changes in taxes, social security contributions and possible additional benefits like child benefits. The focus has been on the period 2001 to 2012, covering a wide set of EU countries, both old and new MSs, and also three US states for reference.

First, we do not find a general decrease in minimum wages. In contrast, minimum wages in the mew MSs increased substantially in real terms, and remained relatively stable in the old MSs. Evidence of such a catch-up growth was more limited in relative terms. Variation was already low to begin with. Still, minimum wages in countries where these were low at the start of the observation period caught up to some extent, whereas the minimum wages in the more generous countries lost ground relative to average living standards.

This paper covers a period when concerns with 'making work pay' and in-work poverty grew increasingly more prominent, at least in policy discourse at the international (OECD), European and national level, be it in various degrees and guises. We find that by and large this trend was for real. We see substantial declines in income tax liabilities among minimum wage workers, especially for those living in single adult households that were still facing relatively substantial tax burdens at the start of the observation period. In many countries, the importance of child support through the tax system in the overall net income support seems to have increased. This is consistent with claims that a trend is unfolding towards a fiscalization of income support policies. Finally, we expected that the strongest efforts were aimed at working lone parents, as 
they face the strongest disincentives to take up low-paid work, while in-work poverty is also especially prevalent among this population group. We do find indications that governments stepped up efforts to offer income support for low earnings households and that this happened even more for lone parents as compared to single persons or breadwinner couples.

In a way this is relatively hopeful. Yet the fact of the matter remains that in-work poverty persists even in countries that have taken substantial additional efforts to support households on low earnings. It is worth stressing again that in most EU countries a majority of children growing up in financial poverty live in households that mainly rely on earnings. For many of them this is a long-term affliction when parents (or more often the sole parent) have limited opportunities for upward pay mobility. Thus for the rhetoric of 'making work pay' and 'a job is the best protection against poverty' to become a reality there is still a long way to go in many countries. The question is whether governments will have enough zeal and resources to stem what seems to be an inevitable tide towards fewer decent jobs for the least skilled and yet ever greater competition for these jobs. 


\section{References}

Acemoglu D and Autor D. (2011) Chapter 12 - Skills, Tasks and Technologies: Implications for Employment and Earnings*. In: David C and Orley A (eds) Handbook of Labor Economics. Elsevier, 1043-1171.

Adema W. (1997) What do countries really spend on social policies? a comparative note. OECD economic studies. Paris: OECD.

Annesley C. (2007) Lisbon and social Europe: towards a European 'adult worker model' welfare system. Journal of European Social Policy 17(3): 195-205.

Atkinson A. (2015) Inequality. What can be done?, Harvard: Harvard University Press.

Atkinson AB, Cantillon B, Marlier E, et al. (2002) Social Indicators: The EU and Social Inclusion, Oxford: Oxford University Press.

Aust A and Arriba A. (2005) Towards Activation? Social Assistance Reforms and Discourses. In: Taylor-Gooby P (ed) Ideas and Welfare State Reform in Western Europe. London: Palgrave Macmillan UK, 100-123.

Bengtsson M. (2014) Towards standby-ability: Swedish and Danish activation policies in flux. International Journal of Social Welfare 23(S1): 54-70.

Bradshaw J and Hatland A. (2006) Introduction. In: Bradshaw J and Hatland A (eds) Social Policy, Employment And Family Change In Comparative Perspective. Cheltenham: Edward Elgar.

Cameron D. (2013) Free movement in Europe needs to be less free. Financial Times. London.

Crettaz E. (2013) A state-of-the-art review of working poverty in advanced economies: theoretical models, measurement issues and risk groups. Journal of European Social Policy 23(4): 347-362. 
Daly M. (2011) What Adult Worker Model? A Critical Look at Recent Social Policy Reform in Europe from a Gender and Family Perspective. Social Politics: International Studies in Gender, State \& Society 18(1): 1-23.

Draxler J and Van Vliet O. (2010) European Social Model: No Convergence from the East. Journal of European Integration 32(1): 115-135.

Eichhorst W, Kaufmann O, Konle-Seidl R, et al. (2008) Bringing the Jobless into Work? An Introduction to Activation Policies. In: Eichhorst W, Kaufmann O and Konle-Seidl R (eds) Bringing the Jobless into Work? Experiences with Activation Schemes in Europe and the US. Berlin, Heidelberg: Springer Berlin Heidelberg, 1-16.

Eichhorst W and Konle-Seidl R. (2008) Contingent convergence: a comparative analysis of activation policies. In: IZA (ed) IZA Discussion Paper. Bonn: IZA, 30.

Erhel C and Zajdela H. (2004) The Dynamics of Social and Labour Market Policies in France and the United Kingdom: Between Path Dependence and Convergence. Journal of European Social Policy 14(2): 125-142.

Etherington D and Ingold J. (2012) Welfare to work and the inclusive labour market: a comparative study of activation policies for disability and long-term sickness benefit claimants in the UK and Denmark. Journal of European Social Policy 22: 30-44.

Eurofound. (2014) Labour mobility in the EU: Recent trends and policies. Dublin: Eurofound, 86.

European Commission. (2008) Commission Recommendation of 3 October 2008 on the active inclusion of people excluded from the labour market In: Commission E (ed) Official Journal of the European Union L307. Brussels: European Commission, 11-14.

European Commission. (2010a) EUROPE 2020. A strategy for smart, sustainable and inclusive growth In: Commission E (ed) $\operatorname{COM(2010)~} 2020$. 
European Commission. (2010b) Industrial relations in Europe 2010, Luxembourg: Publications Office of the European Union.

Eurostat. (2015) Statistics by theme.

Ferrarini T, Nelson K and Höög H. (2013) From universalism to selectivity: old wine in new bottles for child benefits in Europe en other countries. In: Marx I and Nelson K (eds) Minimum income protection in flux. Basingstoke: Palgrave Macmillan, 137-160.

Halleröd B, Ekbrand H and Bengtsson M. (2015) In-work poverty and labour market trajectories: Poverty risks among the working population in 22 European countries. Journal of European Social Policy 25(5): 473-488.

Hanzl-Weiß D and Vidovic H. (2010) Working poor in Europe. Dublin: EurWORK.

Immervoll H. (2007) Minimum wages, minimum labour costs and the tax treatment of low-wage employment. IZA Discussion paper series. Bonn: IZA.

Immervoll H. (2012) Reforming the benefit system to make work pay: options and priorities in a weak labour market. IZA policy paper. IZA.

Immervoll H and Pearson M. (2009) A Good Time for Making Work Pay? Taking Stock of In-Work Benefits and Related Measures across the OECD: OECD Publishing.

Knijn T, Martin C and Millar J. (2007) Activation as a Common Framework for Social Policies towards Lone Parents. Social Policy \& Administration 41(6): 638-652.

Kok W. (2004) Facing the challenge. The Lisbon strategy for growth and employment. Report from the High Level Group chaired by Wim Kok. Luxembourg: Office for Official Publications of the European Communities.

Kristal T and Cohen Y. (2016) The causes of rising wage inequality: the race between institutions and technology. Socio-Economic Review. 
Kvist J. (2004) Does EU enlargement start a race to the bottom? Strategic interaction among EU member states in social policy. Journal of European Social Policy 14: 301.

Marx I, Marchal S and Nolan B. (2013) Mind the gap: net incomes of minimum wage workers in the EU and the US. In: Marx I and Nelson K (eds) Minimum income protection in flux. Houndmills: Palgrave, 54-80.

Marx I and Verbist G. (1998) Low-paid work and poverty: a cross-country perspective. Low-wage employment in Europe / Bazen, Stephen [edit.]. Cheltenham: Elgar, 63-86.

McBride S and Williams RA. (2001) Globalization, the Restructuring of Labour Markets and Policy Convergence: The OECD 'Jobs Strategy'. Global social policy 1(3): 281-309.

Montanari I, Nelson K and Palme J. (2008) Towards a European social model? European Societies 10(5): 787-810.

OECD. (1994) The OECD jobs study, Paris: OECD.

OECD. (1997) The OECD Job Strategy. Making Work Pay: Taxation, Benefits, Employment. Paris: OECD.

OECD. (2003) Making Work Pay. Making Work Possible. OECD Employment Outlook: 2003. Paris: OECD, $114-170$.

OECD. (2005) Extending opportunities: how active social policy can benefit us all, Paris: OECD.

OECD. (2009) Employment outlook: tackling the jobs crisis, Paris: OECD.

OECD. (2015a) Minimum wages after the crisis: Making them pay. Paris: Directorate for Employment, Labour and Social Affairs.

OECD. (2015b) OECD Stat.Extracts. 
Paetzold J and Van Vliet O. (2012) Convergence without hard criteria: does EU soft law affect domestic unemployment protection schemes? Working papers in Economics and finance. University of Salzburg.

Ryckx F and Kampelmann S. (2012) Who earns minimum wages in Europe? New evidence based on household surveys. ETUI Report. Brussels: European trade union institute.

Scharpf FW. (2002) The European Social Model: Coping with the Challenges of Diversity. Journal of common market studies 40(4): 645-670.

Schmitt C and Starke P. (2011) Explaining convergence of OECD welfare states: a conditional approach. Journal of European Social Policy 21(120-133).

Skedinger P. (2010) Employment protection legislation: evolution, effects, winners and losers, Cheltenham: Edward Elgar.

Skevik A. (2006) Working their way out of poverty? Lone mothers in policies and labour markets. In: Bradshaw J and Hatland A (eds) Social Policy, Employment And Family Change In Comparative Perspective. Cheltenham: Edward Elgar.

Van Lancker W, Ghysels J and Cantillon B. (forthcoming) The impact of child benefits on single mother poverty: exploring the role of targeting in 15 European countries. International Journal of Social Welfare.

Van Lancker W and Van Mechelen N. (forthcoming) Universalism under siege? Exploring the association between targeting, child benefits and child poverty across 26 countries. Social Science Research.

Van Mechelen N, Marchal S, Goedemé T, et al. (2011) The CSB-Minimum Income Protection Indicators dataset (CSB-MIPI). CSB Working Paper Series. Antwerp: Herman Deleeck Centre for Social Policy, University of Antwerp, 104. 
Van Mechelen N and Bradshaw J. (2013) Child Poverty as a Government Priority: Child Benefit Packages for Working Families, 1992-2009. In: Marx I and Nelson K (eds) Minimum Income Protection in Flux. Palgrave Macmillan, 81-107.

Van Rie T and Marx I. (2012) The EU at work? The European employment strategy from crisis to crisis. Journal of common market studies 50(2): 1-28.

Van Vliet O, Caminada K and Goudswaard K. (2010) Patterns of welfare state indicators in the EU: is there convergence. Journal of common market studies 48(3): 529-556.

Vandenbroucke F and Vinck J. (2013) Child Poverty Risks in Belgium, Wallonia, Flanders: Accounting for a Worrying Performance. In: Maystadt P, Cantillon E, Denayer L, et al. (eds) Le modèle social belge : quel avenir ? Charleroi: Presses interuniversitaires de Charleroi.

Vaughan-Whitehead D. (2010) The minimum wage revisited in the enlarged EU, Cheltenham: Edward Elgar.

Verschueren H. (2015) Preventing 'benefit tourism' in the EU: a narrow or broad interpretation of the possibilities offered by the ECJ in DANO? Common Market Law Review 52(2): 363390.

Weishaupt T. (2011) From the Manpower Revolution to the Activation Paradigm: Explaining Institutional Continuity and Change in an Integrating Europe, Amsterdam: Amsterdam University Press. 